\section{EFFECTS OF REPEATED-SPRINT TRAINING IN HYPOXIA ON PHYSICAL PERFORMANCE OF TEAM SPORTS PLAYERS}

\author{
EFEITOS DO TREINAMENTO DE SPRINTS REPETIDOS EM HIPÓXIA SOBRE A PERFORMANCE FISICA DOS \\ JOGADORESDEESPORTES COLETIVOS
}

EFECTOS DEL ENTRENAMIENTO DE SPRINTS REPETIDOS EN HIPOXIA SOBRE EL DESEMPEÑO FÍSICO DE LOS JUGADORESDEDEPORTES COLECTIVOS

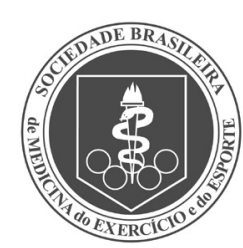

Original Article Artigo OrIGINAL Artículo Original

\author{
Alba Camacho-Cardenosa' \\ (Physician) \\ Marta Camacho-Cardenosa' (iD \\ (Physician) \\ Ismael Martínez-Guardado' (ID \\ (Physician) \\ Javier Brazo-Sayavera ${ }^{3}$ (D) \\ (Physician) \\ Rafael Timon' (ID \\ (Physician) \\ Guillermo Olcina' (iD \\ (Physician) \\ 1. Universidad de Extremadura, \\ Facultad de Ciencias del Deporte, \\ Cáceres, Spain. \\ 2. Universidad de la República, \\ Centro Universitario Regional \\ Noreste, Uruguay.
}

Correspondence: Alba Camacho-Cardenosa Faculty of Sport Science. Av. Universidad, s/n, Cáceres, Espanha, 10003.albacc@unex.es

\begin{abstract}
Introduction: The traditional hypoxic training program used by endurance athletes was included in the training of team and/or racquet sports players. Objective: The aim of this study is to analyse the effect of a new lower dose of repeated-sprint training in hypoxia (RSH) as compared with previous studies on short and long-term physical performance of team sports players. Methods: Tests were performed before and after four weeks of supervised specific training and after two weeks of detraining. Twenty-four team-sport players voluntarily participated in the study (age: $22.73 \pm 2.87$ years; weight: $70.20 \pm 3.42$ kg; height: $176.95 \pm 1.63 \mathrm{~cm}$; BMI: $22.42 \pm 2.26$ $\mathrm{kg} / \mathrm{m} 2)$; the participants were randomly assigned to the $\mathrm{RSH}$ training group $\left(\mathrm{n}=8 ; \mathrm{FiO}_{2}=14.6 \%\right)$, to the normoxia group (RSN) $\left(n=8 ; \mathrm{FiO}_{2}=20.9 \%\right)$ or to a third control group (CON) $(n=8)$. The participants performed eight training sessions of two sets of five 10-second repeated sprints, with a recovery period of 20 seconds between sprints and a recovery period of 10 minutes at $120 \mathrm{~W}$ between sets. Body composition was measured following standard anthropometric evaluation procedures. The Wingate Test, Repeated-Sprint Ability Test, SJ, CMJ and Yo-Yo Intermittent Recovery Test were used to evaluate aerobic and anaerobic outcomes. Results: In the hypoxia group, maximal power increased by $14.96 \%$ and the total number of sprints performed increased by $20.36 \%$, both with a large effect size ( $E S=0.78$ and $E S=0.71$, respectively). Conclusion: $A$ lower dose of repeated-sprint training in hypoxia produces improvements in maximal power and number of sprints in the hypoxia group, in team sports players, as shown by the large effect size in both cases. Level of evidence Il; Comparative prospective study.
\end{abstract}

Keywords: Aerobic exercise; Training; Physical fitness; Hypoxia.

\section{RESUMO}

Introdução: O tradicional programa de treinamento em hipóxia utilizado pelos atletas de endurance foi incluído no treinamento dos jogadores de esportes coletivos e/ou de raquete. Objetivo: O objetivo do presente estudo consiste em analisar o efeito de uma nova dose menor de treinamento de sprints repetidos em hipóxia (SRH), em comparação com estudos anteriores sobre o desempenho físico de curto e longo prazo dos jogadores de esportes coletivos. Métodos: Os testes foram realizados antes e após quatro semanas de treinamento específico supervisionado e após duas semanas de destreinamento. Vinte e quatro jogadores de esporte coletivo participaram voluntariamente no estudo (idade: $22,73 \pm 2,87$ anos; peso: 70,20 $\pm 3,42 \mathrm{~kg}$; estatura: $176,95 \pm 1,63 \mathrm{~cm}$; IMC: $22,42 \pm 2,26 \mathrm{~kg} / \mathrm{m} 2$ ); os participantes foram aleatoriamente designados para o grupo de treinamento $\mathrm{SRH}(\mathrm{n}=8 ; \mathrm{FiO2}=14,6 \%)$ ou para o grupo de normóxia (SRN) $(n=8 ; F i O 2=20,9 \%)$ ou para um terceiro grupo controle (CON) $(n=8)$. Os participantes realizaram oito sessões de treinamento de duas séries de cinco sprints repetidos de 10 segundos com período de recuperação de 20 segundos entre os sprints e de 10 minutos a 120 Wentre as séries. A composição corporal foi medida seguindo os procedimentos padrão de avaliação antropométrica. Para avaliar os desfechos aeróbicos e anaeróbicos, os testes de Wingate, teste de habilidade de sprints repetidos, SJ, CMJ Y Yo-Yo teste de recuperação intermitente foram utilizados. Resultados: No grupo hipóxia, a potência máxima aumentou em 14,96\% e o número total de sprints realizado aumentou em 20,36\%, ambos apresentaram grande tamanho de efeito ( $E S=0,78$ eES $=0,71$, respectivamente). Conclusão: Uma dose menor de treinamento de sprints repetidos em hipóxia leva a melhorias na potência máxima e no número de sprints no grupo hipóxia em jogadores de esportes coletivos, conforme demonstrado através do grande tamanho de efeito em ambos os casos. Nível de evidência ll; Estudo prospectivo comparativo.

Descritores: Exercício aeróbico; Treinamento; Aptidão física; Hipóxia.

\section{RESUMEN}

Introducción: El tradicional programa de entrenamiento en hipoxia utilizado por los atletas de endurance fue incluido en el entrenamiento de los jugadores de deportes colectivosy/o de raqueta. Objetivo: El objetivo del presenteestudio consiste en analizar el efecto de una nueva dosis menor de entrenamiento de sprints repetidos en hipoxia (SRH), en comparación con estudios anteriores sobre el desempeño físico de corto y largo plazo de los jugadores de deportes colectivos. Métodos: Los tests fueron realizados antes y después de cuatro semanas de entrenamiento especifico supervisado y después de dos 
semanas de desentrenamiento. Veinticuatro jugadores de deporte colectivo participaron voluntariamente en el estudio

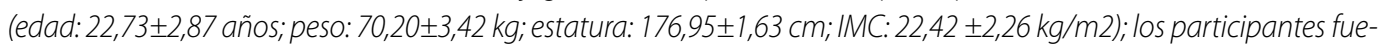
ron aleatoriamente designados para el grupo de entrenamiento $S R H(n=8 ; F i O 2=14,6 \%$ ) o para el grupo de normoxia $(S R N)(n=8 ; F i O 2=20,9 \%)$ o para un tercer grupo control (CON) $(n=8)$. Los participantes realizaron ocho sesiones de entrenamiento de dos series de cinco sprints repetidos de 10 segundos con periodo de recuperación de 20 segundos entre los sprints y de 10 minutos a 120 W entre las series. La composición corporal fue medida siguiendo los procedimientos estándar de evaluación antropométrica. Para evaluar los resultados aeróbicos y anaeróbicos, fueron utilizados los tests de Wingate, test de habilidad de sprints repetidos, SJ, CMJ y Yo-Yo test de recuperación intermitente. Resultados: En el grupo hipoxia, la potencia máxima aumentó en 14,96\% y el número total de sprints realizado aumentó en 20,36\%, ambos presentaron gran tamaño de efecto ( $E S=0,78$ y ES $=0,71$, respectivamente). Conclusión: Una dosis menor de entrenamiento de sprints repetidos en hipoxia lleva a mejoras en la potencia máxima y en el número de sprints en el grupo hipoxia en jugadores de deportes colectivos, conforme fuera demostrado a través del gran tamaño de efecto en ambos casos. Nivel de evidencia ll; Estudio prospectivo comparativo.

Descriptores: Ejercicio aeróbico; Entrenamiento; Aptitud física; Hipoxia.

\section{INTRODUCTION}

Team sports are activities have experienced an increase in the time of play and energy demands during matches. ${ }^{1}$ Moreover, during convalescence periods the level of physical conditioning and ability to recuperate are modified. The physical demands require speed, agility, muscular power and endurance. ${ }^{2}$ Although the decisive actions of team sports are high-intensity activities, aerobic metabolism plays an important role., ${ }^{3,4}$ Considering the physiological requirements and high demands of team-sport match-play, training modalities that specifically enhance the capacity to repeat high-intensity efforts could have clear benefits for these athletes. 5,6 For these reasons, coaches often seek training strategies based on repeated maximum intensity efforts which allow meeting aerobic and anaerobic demands in this type of sports in less time. The traditional panorama of hypoxic/altitude training used by endurance athletes has been updated by team-and/or racquet-sport players. ${ }^{1}$ The so-called "repeated-sprint training in hypoxia" (RSH), based on the repetition of "all-out" efforts of short duration with incomplete recoveries", are increasingly popular in this field. A meta-analysis that compared $\mathrm{RSH}$ with similar repeated-sprint in normoxia (RSN) demonstrated improvements in repeated sprinting performance and fatigue resistance in favour of $\mathrm{RSH}^{8}$ For example, with well-trained rugby players ${ }^{8}$ intermittent running performance improved by $33 \%$ after 120 running sprints of 6 seconds, using the Yo-Yo Intermittent Recovery Test (YYIR).

The efficacy of this training could be related to increase in muscle blood flow (compensatory vasodilation) and greater microvascular oxygen delivery to fast-twitch fibers ${ }^{9,10}$, mediated by an oxygen-sensing pathway. ${ }^{11}$ During repeated sprint, inorganic phosphate (Pi) accumulates in muscles. These increased Pi levels may participate in decreasing the ability for force production, especially in fast-twitch fibers. However, the adaptations achieved with hypoxic stimulus might allow for removal of these waste metabolites and thus delay the fatigue. ${ }^{12}$

Regarding the specific protocol, more studies are still needed to demonstrate the efficacy of these new training methods on the performance of team-sport players, particularly in specific physical conditions. ${ }^{13}$ Selection of an appropriate hypoxic dose will be critical to maximise training adaptation, since if too severe, this is likely to compromise training quality, and hence affect the possible benefits to be derived from a greater physiological load. So, the aim of this study is therefore to analyse the effect of a new lower dose of RSH as compared with previous studies, on short and long-term physical performance of team-sport players.

\section{MATERIAL AND METHODS}

A total of 24 volunteers participated in the study ( $n=24$; age: $22.73 \pm 0.87$ years; weight: $70.20 \pm 3.42 \mathrm{~kg}$; height: $176.9 \pm 0.57 \mathrm{~cm} ; \mathrm{BMl}$ : $\left.22.42 \pm 2.26 \mathrm{~kg} / \mathrm{m}^{2}\right)$. The participants were healthy adults, who were not being subjected to any dietary supplementation plan nor acclimatized or recently exposed to altitudes of more than $1800 \mathrm{~m}$. All volunteers were team-sport recreational players coming from different sports clubs. They were randomly assigned to three groups: repeated sprint ability either in normoxia (RSN, $n=8)$ or hypoxia $(\mathrm{RSH}, \mathrm{n}=8)$ or control group $(\mathrm{CON}, \mathrm{n}=8)$ which completed only testing sessions. The subjects were informed of the experimental protocol and signed the free and informed consent term. This project was approved by the Bioethics Committee of the University of Extremadura and carried out according to the Declaration of Helsinki. Participant's characteristics are shown in Table 1.

\section{Measures}

Three testing sessions were performed by blinded assessors: before (Pre-); a four-weeks supervised specific training session 48 hours after the last session (Post-); and a third session after two weeks of recovery from this training (Det-). During these two weeks of hypoxia detraining they maintained the same physical activity level as they had done before the intervention. Height, weight and body mass index were measured following standard procedures. Subjects performed a standard 30 seconds Wingate Test on the same cyclosimulator with integrated potentiometer (Cycleops 410 pro, Cycleops, Madison, USA) as in the training sessions. Maximal and mean power and peak and average rate were registered. Five minutes after the end of the test, lactate concentration was evaluated with a tap in the earlobe with Lactate Scout strips (SensLab, Leipzig, Germany). The subjects conducted a repeated sprint test under normoxic conditions, comprising the largest number of 10 seconds all-out sprints (maximal pedalling) with a 20 -sec active rest between sprints at $120 \mathrm{~W}$. Subjects were given very strong verbal encouragement and performed as many sprints as possible until exhaustion. A minimum of 70 rpm after 5 seconds or less of sprinting was set as a criterion to stop the subjects

Table 1. Characteristics control (CON), normoxia (RSN) and hypoxia (RSH) groups.

\begin{tabular}{c|c|c|c|c}
\hline & $\begin{array}{c}\text { Age } \\
\text { (years) }\end{array}$ & $\begin{array}{c}\text { Weight } \\
\mathbf{( k g )}\end{array}$ & $\begin{array}{c}\text { Height } \\
(\mathbf{c m})\end{array}$ & $\begin{array}{c}\text { BMI } \\
\left(\mathbf{k g} / \mathbf{m}^{2}\right)\end{array}$ \\
\hline $\operatorname{CON}(8)$ & $22.7 \pm 3.2$ & $69.3 \pm 4.2$ & $178.0 \pm 1.1$ & $21.9 \pm 3.7$ \\
\hline RSN (8) & $22.5 \pm 2.9$ & $70.1 \pm 3.1$ & $175.8 \pm 2.8$ & $22.7 \pm 0.4$ \\
\hline RSH (8) & $23.1 \pm 2.5$ & $71.3 \pm 3.0$ & $177.0 \pm 1.1$ & $22.7 \pm 2.6$ \\
\hline
\end{tabular}

RSH: Repeated-Sprint Hypoxia Group; RSN: Repeated-Sprint Normoxia Group; CON: Control Group; BMl: body mass index. 
test. ${ }^{14}$ Number of sprints, maximal power and average power output for each sprint were registered. Squat Jump (SJ) and Counter Movement Jump (CMJ) were tested using an Optojump System (OptojumpNext, Microgate, Bolzano, Italia) ${ }^{15}$ Twenty-meter shuttle runs were performed at increasing velocities, with 10-s periods of active recovery between runs, until the participants were exhausted. ${ }^{16}$ The total distance covered (including the last incomplete shuttle) was considered as the Yo-Yo Test performance and the velocity associated with this final stage was considered as the individual's $\mathrm{VO}_{2}$ peak, which is estimated by the formula: $\mathrm{VO}_{2}$ peak $\left(\mathrm{ml} \cdot \mathrm{min} \cdot \mathrm{kg}^{-1}\right)=24.8+\left(0.014^{*}\right.$ distance in meters $)$.

The randomized controlled trial based on a longitudinal experimental protocol consisted in a similar protocol used in a previous study carried out by Faiss, et al. ${ }^{14}$ Volunteers completed eight specific cycling training sessions with repeated sprints over four weeks. Participants performed two sessions per week in a hypoxic chamber (CAT 310, Colorado Altitude Training, Louisville, USA) built in our laboratory at an altitude of $457 \mathrm{~m}$ in Cáceres (Spain). The RSH group breathed an oxygen fraction $\left(\mathrm{FiO}_{2}\right)$ at 14.6\% (to simulate an altitude of $3,400 \mathrm{~m}$ ), controlled with an electronic device (HANDI+, Maxtec, Salt Lake City, Utah, USA). In order to blind volunteers to altitude, the system also ran for RSN with normoxic airflow into the chamber. Training sessions were performed in the same cyclosimulator with integrated potentiometer (Cycleops 410 pro, Cycleops, Madison, USA). Following a 10 minutes warm-up at $120 \mathrm{~W}$, all training sessions consisted of two sets of five repeated 10-seconds sprints with a recovery of 20 seconds between sprints and a recovery period of 10 minutes at $120 \mathrm{~W}$ between sets, ending with a five min recovery at $120 \mathrm{~W}$. The maximum power of each sprint was registered and monitored by the potentiometer in real time via the potentiometer data screen itself. Between training sessions there were at least 48 hours of rest for an optimal recovery.

\section{Statistical analyses}

The results are presented as mean \pm SD. The statistical package SPSS v.20 for MAC (IBM, New York, USA) was used for the statistical analysis. In addition, before the analysis, for all variables the Kolmogorov-Smirnov test for normality of distribution and Levene's test for homogeneity of variance were calculated. To compare responses in each variable across the two time points, an ANOVA for repeated-measures was used. When a global difference over time was determined, Bonferroni post hoc analysis was used to identify where changes occurred. The $p<0.05$ criterion was used for establishing statistical significance. The effect size was calculated for all variables between pre and post-testing. The magnitude of the difference was considered small (0.2), moderate (0.5), or large (0.8).

\section{RESULTS}

The results from the Wingate Test and All-out Test are shown in Table 2. Although no statistically significant differences were found, maximal power and number of sprints improved in the hypoxia group with a large effect size.

Regarding the maximal power, no statistically significant difference was found. However, this parameter increased especially in the hypoxia group after a training program with a large effect size, but not after two weeks of post-intervention. Blood lactate concentration decreased in the hypoxia group after the intervention period. But, after two weeks of post-intervention, blood lactate concentration increased until baseline level in the hypoxia groups. Peak and average heart rate decreased in the hypoxia group after intervention and these changes were maintained after two weeks of post-intervention. Although no statistically significant difference was found, the hypoxia group showed a large effect size between baseline-post-intervention and baseline-detraining in this parameter. Mean power revealed no significant change in the normoxia and hypoxia group.
The training effects upon specific physical conditioning in team sports like repeated sprint ability and jump performance are shown in Figure 1. The number of sprints improved in both the normoxia and hypoxia groups, but not significantly. However, in the hypoxia group, the number of sprints increased with a large effect size. Jumping performance was evaluated with the SJ and CMJ Tests. In the SJ, the performance only increased slightly in the hypoxia group after the training program but with a small effect size.

Finally, training effects regarding the performance aerobic parameters of the Yo-Yo Test are shown in Table 3. Distance performed in this test increased in the hypoxia group in the post-intervention and detraining as compared with the baseline. However, in the normoxia group the performance increased in post-intervention when compared with the baseline, but not between the detraining and baseline. Although the distance performed increased, $\mathrm{VO}_{2}$ max was not affected.

The control group did not suffer important changes in any of the variables. No statistically significant difference was found in either of these parameters, neither in intra group analysis nor in between group analysis.

Table 2. Wingate test performance before and after intervention.

\begin{tabular}{|c|c|c|c|c|c|c|}
\hline & $\begin{array}{l}\text { Baseline } \\
\text { (A) }\end{array}$ & $\begin{array}{l}\text { Post- } \\
\text { (B) }\end{array}$ & $\begin{array}{l}\text { Detraining } \\
\text { (C) }\end{array}$ & $\begin{array}{l}\Delta(\%) \\
(\mathrm{A}-\mathrm{B})\end{array}$ & $\begin{array}{l}\Delta(\%) \\
(\mathrm{A}-\mathrm{C})\end{array}$ & $\begin{array}{l}\Delta(\%) \\
\text { (B-C) }\end{array}$ \\
\hline \multicolumn{7}{|c|}{ Lactate $(\mathrm{Mmol} / \mathrm{L})$} \\
\hline CON (8) & $10.7 \pm 2.6$ & $10.2 \pm 1.8$ & $10.8 \pm 0.6$ & -4.7 & 0.9 & 5.9 \\
\hline RSN (8) & $11.3 \pm 1.1$ & $9.8 \pm 2.2$ & $11.3 \pm 1.3$ & -13.0 & 0.2 & 15.1 \\
\hline RSH (8) & $10.5 \pm 2.9$ & $10.0 \pm 1.6$ & $11.8 \pm 0.5$ & -4.8 & 12.4 & 18.0 \\
\hline \multicolumn{7}{|c|}{$\operatorname{Max} P(W)$} \\
\hline CON (8) & $722 \pm 125$ & $733 \pm 129$ & $741 \pm 101$ & 1.5 & 2.7 & 1.2 \\
\hline RSN (8) & $712 \pm 115$ & $713 \pm 119$ & $721 \pm 91$ & 0.1 & 1.3 & 1.3 \\
\hline RSH (8) & $742 \pm 135$ & $853 \pm 149$ & $751 \pm 81$ & 15.0 & 1.3 & -11.9 \\
\hline \multicolumn{7}{|c|}{ Mean $\mathrm{P}(\mathrm{W})$} \\
\hline CON (8) & $467 \pm 25$ & $450 \pm 58$ & $476 \pm 34$ & -3.6 & 1.8 & 5.6 \\
\hline RSN (8) & $403 \pm 160$ & $448 \pm 188$ & $441 \pm 157$ & 11.2 & 9.4 & $-1,5$ \\
\hline RSH (8) & $434 \pm 73$ & $440 \pm 74$ & $470 \pm 120$ & 1.3 & 8.3 & 6.9 \\
\hline \multicolumn{7}{|c|}{ HRmax (bpm) } \\
\hline CON (8) & $182.3 \pm 9.2$ & $181.7 \pm 9.7$ & $181.1 \pm 15.8$ & -0.3 & -0.6 & -0.3 \\
\hline RSN (8) & $184.7 \pm 9.1$ & $180.7 \pm 9.9$ & $182.3 \pm 16.6$ & -2.2 & -1.2 & 0.9 \\
\hline RSH (8) & $181.7 \pm 10.6$ & $169.2 \pm 12.3$ & $170.5 \pm 11.0$ & -6.9 & -6.2 & 0.7 \\
\hline \multicolumn{7}{|c|}{ HRave (bpm) } \\
\hline CON (8) & $161.1 \pm 32.2$ & $157.0 \pm 31.4$ & $160.7 \pm 41.1$ & -2.5 & -0.3 & 2.3 \\
\hline RSN (8) & $163.3 \pm 34.2$ & $156.0 \pm 32.4$ & $159.7 \pm 40.8$ & -4.5 & -2.2 & 2.3 \\
\hline RSH (8) & $159.7 \pm 13.1$ & $149.2 \pm 20.6$ & $153.2 \pm 15.1$ & -6.6 & -4.1 & 2.7 \\
\hline
\end{tabular}

RSH: Repeated-Sprint Hypoxia Group; RSN: Repeated-Sprint Normoxia Group; CON: Control Group; Max P: Maxima Power; Mean P: Mean Power; HRmax: Maximal Heart Rate; HRave: Heart Rate average; bpm: beats per minute

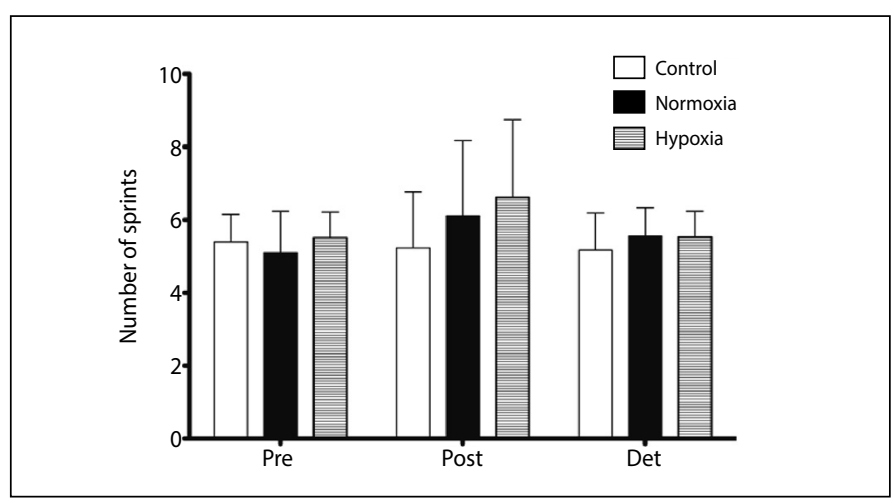

Figure 1. Number of sprints before and after intervention. 
Table 3. Jump and Yo-Yo Test Performance before and after intervention.

\begin{tabular}{|c|c|c|c|c|c|c|}
\hline & $\begin{array}{l}\text { Baseline } \\
\text { (A) }\end{array}$ & $\begin{array}{l}\text { Post- } \\
\text { (B) }\end{array}$ & $\begin{array}{l}\text { Detraining } \\
\text { (C) }\end{array}$ & $\begin{array}{l}\Delta(\%) \\
(\mathrm{A} / \mathrm{B})\end{array}$ & $\begin{array}{l}\Delta(\%) \\
(\mathrm{A} / \mathrm{C})\end{array}$ & $\begin{array}{l}\Delta(\%) \\
(B / C)\end{array}$ \\
\hline \multicolumn{7}{|c|}{ SJ $(\mathrm{cm})$} \\
\hline CON (8) & $34.0 \pm 14.7$ & $32.7 \pm 1.2$ & $30.8 \pm 14.4$ & -3.7 & -9.4 & -5.9 \\
\hline RSN (8) & $37.5 \pm 9.3$ & $35.9 \pm 9.5$ & $29.9 \pm 5.8$ & -4.3 & -20.2 & -16.7 \\
\hline RSH (8) & $43.2 \pm 20.4$ & $45.9 \pm 15.0$ & $46.7 \pm 15.4$ & 6.18 & 8.0 & 1.7 \\
\hline \multicolumn{7}{|c|}{$\mathrm{CMJ}(\mathrm{cm})$} \\
\hline $\operatorname{CON}(8)$ & $37.3 \pm 18.1$ & $36.8 \pm 1.2$ & $36.7 \pm 19.2$ & -1.4 & -1.1 & 0.2 \\
\hline RSN (8) & $39.5 \pm 9.3$ & $38.8 \pm 8.2$ & $32.3 \pm 6.1$ & -1.9 & -18.4 & -16.8 \\
\hline RSH (8) & $46.6 \pm 21.7$ & $50.3 \pm 16.7$ & $48.1 \pm 16.4$ & 8.0 & -3.3 & -4.4 \\
\hline \multicolumn{7}{|c|}{ Distance (m) } \\
\hline $\operatorname{CON}(8)$ & $920.0 \pm 614.9$ & $936.4 \pm 502.0$ & $901.0 \pm 343.9$ & 1.8 & -2.1 & -3.8 \\
\hline RSN (8) & $880.0 \pm 635.0$ & $906.6 \pm 522.0$ & $880.0 \pm 393.9$ & 3.0 & 0.0 & -2.9 \\
\hline RSH (8) & $1053.3 \pm 553.5$ & $1220.0 \pm 645.3$ & $1160.0 \pm 637.0$ & 15.8 & 10.1 & -4.9 \\
\hline \multicolumn{7}{|c|}{$\mathrm{VO}_{2} \max (\mathrm{kg} / \mathrm{L} / \mathrm{min})$} \\
\hline $\operatorname{CON}(8)$ & $37.52 \pm 8.69$ & $37.79 \pm 7.21$ & $37.02 \pm 5.32$ & 0.72 & -1.33 & -2.04 \\
\hline RSN (8) & $37.12 \pm 8.89$ & $37.49 \pm 7.31$ & $34.32 \pm 5.52$ & 1.00 & -7.54 & -8.46 \\
\hline RSH (8) & $39.55 \pm 7.75$ & $41.88 \pm 9.03$ & $41.04 \pm 8.92$ & 5.89 & 3.77 & -2.01 \\
\hline
\end{tabular}

\section{DISCUSSION}

In the present study, the aim was to analyse the effect of a new lower dose of RSH compared with previous studies, on short and long-term physical performance of team-sport players. In the first instance our protocol does not show significant changes, however the increase in large effect sizes found in the number of sprints developed in the All-out Test and the highest maximal power leads us to think that significant changes could be obtained from a higher sampling. In any case, finding no significant differences, the results must be taken with caution. According to previous studies, the main advantage of using RSH training could be the improvements found in relation to repeated sprint ability and resistance fatigue, very relevant to team sports. ${ }^{7}$ Some studies ${ }^{17}$ suggest that for athletes who require a specific, supramaximal exercise stimulus, the addition of hypoxia to an anaerobic exercise regimen could lead to muscular and metabolic stimulus that cannot be attained with training alone.

The maximal power increased in the hypoxia group between baseline and post-intervention. Although these results had no significant changes, the large effect size ( $E S=0.78$ ) could suggest that the RSH group had further benefits in repeated sprint ability. Previous studies have shown that this type of training could be beneficial for maximum performance. ${ }^{14,18,19}$ Thus, in a study with lacrosse players, ${ }^{18}$ peak power improved after repeated sprint exercise in hypoxia (RSH) to a greater extent than under normoxic conditions.

Repetition of short efforts interspersed with short and incomplete recovery under hypoxia conditions result in a lower fatigue slope. ${ }^{20}$ The findings of the present study are supported by other authors who obtained a significant increase in the number of sets until exhaustion during the repeated sprint test in hypoxia. ${ }^{14,21}$ However, after two-weeks ceasing of stimulus sprint the number of sprints decreased. Perhaps the lower load of training could indicate that a longer training program is necessary. During sprints in RSH, decreasing oxygen contributed greatly to the mechanism of compensatory vasodilation, and was particularly important for fast-twitch:20 given the high intensity of exercise, this compensatory vasodilation could be high to ensure complete delivery of oxygen to the muscle ${ }^{9}$ Moreover, this higher blood perfusion produced after RSH favors phosphocreatine resynthesis, which is paramount for maintaining power production. However, in this study the method used provided only an indirect estimation of muscle perfusion variations (and thus blood flow) and our interpretations should be considered with care. Opposite results found in this study could be produced by a state of overtraining or fatigue. Performance impairment during repeated long (i.e. $\geq 30$ s) and all-out sprints may be more essentially related to central fatigue. ${ }^{22}$ During repeated-sprint exercises similar findings have been reported, with endurance-trained athletes showing less fatigue than team-sport athletes. ${ }^{23}$ Maintenance or a slight increase in the average power during the Wingate Test would confirm this hypothesis, eliminating the possibility that the subjects did not perform all tests at their full capacity. In addition, all subjects underwent a phase of previous familiarization to assure the correct development of the evaluations.

It is well known that aerobic training is necessary during recovery to eliminate the high waste concentration produced by high-intensity actions. If oxygen availability is impaired, lactate accumulates, limiting the player's ability to sustain a high power output..$^{24}$ Gatterer, et al. ${ }^{25}$ following a specific hypoxia training session for team sports, found no improvement in the YYIRTest outcomes. However, Galvin, et al. ${ }^{8}$ obtained an improvement in the distance performed and $\mathrm{VO}_{2}$ max when compared to RSN. According to previous studies, muscular oxidative activity might be less influenced by such training, which could explain why no hypoxia effect on the YYIR outcome was found..$^{14,25}$

Similarly to previous studies where repeated sprints were performed, ${ }^{26,27}$ no statistical changes were found in lower limb explosive strength. The low specificity of the test with regard to the type of intervention could be the cause of the findings. Improvements in these types of test appear in specific strength-training programs. ${ }^{28} \mathrm{~A}$ study on youth football players showed improvements in lower limb explosive strength and sprinting after sprints repeated in hypoxia. These improvements could be due to neural adaptations: increased motor unit synchronization and/or agonist muscle activation. ${ }^{29}$

Some limitations should be considered. The severity of altitude, time spent training at altitude, or type of training represent important factors to consider when designing a training program at altitude. A recent meta-analysis by Brocherie, et al. ${ }^{7}$ suggested recommendations regarding the $\mathrm{RSH}$ protocol to elicit significant improvements. The lowest volume used in terms of sets could explain why no significant changes were shown. A training regime and tests more specific to these sports could have produced improvements in the same parameters. The small sample-size certainly is a weakness in this study. Despite this, there are significant indications that this type of training could have benefits for these athletes as shown by the high effect sizes. Benefits from this type of training appear between pre and post evaluation but not after two weeks of training. This aspect could be relevant in relation to the training planning. An RSH program could be included at an important stage in the season to produce a peak performance, for example before the final phases. So, coaches should take into account this "timing" of benefits in applying the sprints in hypoxia in different training-season moments.

In conclusion, a lower dose of Repeated-Sprint Hypoxia produces improvements in maximal power and number of sprints in the hypoxia group, in team-sports players, as is shown by such a large effect size in both cases. This could lead to improvements in maximum performance and delayed onset of fatigue in repeated high-intensity actions. However, it does not appear to be effective in improving aerobic capacity nor jump performance. Further studies with protocols designed for double-blind, large sample size and specific training for team sports are needed to support the effectiveness of RSH. 


\section{ACKNOWLEDGMENTS}

The project has been supported by the Government of Extremadura with funding from the European Regional Development Fund under Grant (Ref: GR18003) and the Ministry of Education, Culture and Sports, under Grant FPU15/00450 and FPU15/00452. We would like to acknowledge the contribution of Dr. Átila Trapé for his assistance and inestimable help in the translate to portuguese of original manuscript.

All authors declare no potential conflict of interest related to this article

AUTHORS' CONTRIBUTIONS: Each author made significant individual contributions to this manuscript. ACC and MCC: data analysis and writing of the manuscript; IMG: acquisition and analysis of data; JBS: statistical analysis, edition and revision; RT: statistical analysis and elaboration of the entire research project; GO: elaboration of the entire research project and intellectual content of the manuscript. All authors approved the final version of the manuscript.

\section{REFERENCES}

1. Girard O, Amann M, Aughey R, Billaut F, Bishop DJ, Bourdon P, et al. Position statement-altitude training for improving team-sport players' performance: current knowledge and unresolved issues. Br J Sports Med. 2013;47(Suppl 1):i8-16

2. Bishop DJ, Girard O. Determinants of team-sport performance: implications for altitude training by team-sport athletes. Br J Sports Med. 2013;47(Suppl 1):i17-21.

3. Stolen T, Chamari K, Castagna C, Wisloff U. Physiology of soccer: an update. Sports Med. 2005;35(6):501-36.

4. Faude $\mathrm{O}$, Koch T, Meyer T. Straight sprinting is the most frequent action in goal situations in professional football. J Sports Sci. 2012;30(7):625-31.

5. Buchheit M, Mendez-Villanueva A, Delhomel G, Brughelli M, Ahmaidi S. Improving repeated sprint ability in young elite soccer players: repeated shuttle sprints vs. explosive strength training. J Strength Cond Res. 2010;24(10):2715-22

6. Serpiello FR, McKenna MJ, Bishop DJ, Aughey RJ, Caldow MK, Cameron-Smith D, et al. Repeated sprints alter signaling related to mitochondrial biogenesis in humans. Med Sci Sports Exerc. 2012;44(5):827-34.

7. Brocherie F, Girard O, Faiss R, Millet GP. Effects of repeated-sprint training in hypoxia on sea-level performance: a meta-analysis. Sports Med. 2017.

8. Galvin HM, Cooke K, Sumners DP, Mileva KN, Bowtell JL. Repeated sprint training in normobaric hypoxia. Br J Sports Med. 2013;47(Suppl 1):i74-9.

9. Casey DP, Joyner MJ. Compensatory vasodilatation during hypoxic exercise: mechanisms responsible for matching oxygen supply to demand. J Physiol. 2012;590(24):6321-6.

10. Cleland SM, Murias JM, Kowalchuk JM, Paterson DH. Effects of prior heavy-intensity exercise on oxygen uptake and muscle deoxygenation kinetics of a subsequent heavy-intensity cycling and knee-extension exercise. Appl Physiol Nutr Metab. 2012;37(1):138-48.

11. Lundby C, Calbet JA, Robach P. The response of human skeletal muscle tissue to hypoxia. Cell Mol Life Sci. 2009;66(22):3615-23.

12. Westerblad H, Allen DG, Lannergren J. Muscle fatigue: lactic acid or inorganic phosphate the major cause? News Physiol Sci. 2002;17:17-21.

13. Faiss R, Girard O, Millet GP. Advancing hypoxic training in team sports: from intermittent hypoxic training to repeated sprint training in hypoxia. Br J Sports Med. 2013;47(Suppl 1):i45-50.

14. Faiss R, Léger B, Vesin JM, Fournier PE, Eggel Y, Dériaz O, et al. Significant molecular and systemic adaptations after repeated sprint training in hypoxia. PLoS One. 2013;8(2):e56522.

15. Cherif M, Said M, Chaatani S, Nejlaoui O, Gomri D, Abdallah A. The effect of a combined High-Intensity plyometric and Speed Training Program on the running and jumping ability of male handball players. Asian J Sports Med. 2012;3 (1):21-8.
16. Chelly MS, Hermassi S, Aouadi R, Khalifa R, Van den Tillaar R, Chamari K, et al. Match analysis of elite adolescent team handball players. J Strength Cond Res. 2011;25(9):2410-7.

17. Álvarez-Herms J, Julia-Sánchez S, Gatterer H, Viscor G, Burtscher M. Differing levels of acute hypoxia do not influence maximal anaerobic power capacity. Wilderness Environ Med. 2015;26(1):78-82.

18. Kasai N, Mizuno S, Ishimoto S, Sakamoto E, Maruta M, Goto K. Effect of training in hypoxia on repeated sprint performance in female athletes. Springerplus. 2015;4:310.

19. Puype J, Van Proeyen K, Raymackers JM, Deldicque L, Hespel P. Sprint interval training in hypoxia stimulates glycolytic enzyme activity. Med Sci Sports Exerc. 2013;45(11):2166-74.

20. Brocherie F, Girard O, Faiss R, Millet GP. Altitude and team sports: traditional methods challenged by innovative sport-specific training in hypoxia. Rev Int Cien Deporte. 2016;12:338-58.

21. Faiss R, Willis S, Born DP, Sperlich B, Vesin JM, Holmberg HC, et al. Repeated double-poling sprint training in hypoxia by competitive cross-country skiers. Med Sci Sports Exerc. 2015;47(4):809-17.

22. Fernandez-del-Olmo M, Rodriguez FA, Marquez G, Iglesias X, Marina M, Benitez A, et al. Isometric knee extensor fatigue following a Wingate test: peripheral and central mechanisms. Scand J Med Sci Sports. 2013;23(1):57-65

23. Bishop D, Spencer M. Determinants of repeated-sprint ability in well-trained team-sport athletes and endurance-trained athletes. J Sports Med Phys Fitness. 2004;44(1):1-7.

24. Balsom PD, Gaitanos GC, Ekblom B, Sjodin B. Reduced oxygen availability during high intensity intermittent exercise impairs performance. Acta Physiol Scand. 1994;152(3):279-85.

25. Gatterer H, Philippe M, Menz V, Mosbach F, Faulhaber M, Burtscher M. Shuttle-run sprint training in hypoxia for youth elite soccer players: a pilot study. J Sports Sci Med. 2014;13(4):731-5.

26. Brocherie F, Girard O, Faiss R, Millet GP. High-intensity intermittent training in hypoxia: a double-blinded, placebo-controlled field study in youth football players. J Strength Cond Res. 2015;29(1):226-37.

27. Urdampilleta A, Álvarez-Herms J, Martínez-Sanz JM, Corbi F, Roche E. Physical rehabilitation in football by mechanical vibration and hypoxia. Rev Int Med Cienc Act Fís Deporte. 2014;14(53):119-34.

28. Chirosa $\sqcup$, Chirosa IJ, Requena B, Feriche B, Padial P. Efectos de diferentes métodos de entrenamiento de contraste para la mejora de la fuerza de impulsión en un salto vertical. Motricidad. 2002;8:47-71.

29. Manimmanakorn A, Manimmanakorn N, Taylor R, Draper N, Billaut F, Shearman JP, et al. Effects of resistance training combined with vascular occlusion or hypoxia on neuromuscular function in athletes. Eur J Appl Physiol. 2013;113(7):1767-74. 